\title{
PENGARUH PERAN KEPALA SEKOLAH DAN KOMITE SEKOLAH TERHADAP MUTU PENDIDIKAN PADA SMP NEGERI DI KABUPATEN ROKAN HILIR
}

\author{
Suwanto $^{1)}$ \\ Makhdalena $^{2)}$ \\ Azhar $^{3)}$ \\ 1)Post Graduate Student of Riau University \\ ${ }^{2)}$ Lecturer of Education Management Study Programme PPs University of Riau \\ ${ }^{3}$ Lecturer of Education Management Study Programme PPs University of Riau
}

\begin{abstract}
This study aims to determine the headmaster's participation and school committee participation towards eduaction quality on public junior high schools (SMPNs) in Rokan Hilir district. The research was conducted at the Junior High School in Rokan Hilir. the study was conducted over three months, from September 2015 to November 2015. The results show that there is a positive relationship between headmaster's participation and quality of education. Partially, the headmaster's participation affects $90.0 \%$ of the value quality of education at Junior High School in Rokan Hilir, meaning the better headmaster's participation will increase the quality of education. There is a positive relationship between school committee participation with the quality of education. Partially, school committee participation affects $58.3 \%$ of the value of the quality of education at the Junior High School in Rokan Hilir, meaning the better school committee participation will increase the quality of education. There is a positive relationship between the headmaster's participation and school committee participation together with the quality of education. Headmaster's participation and $t$ school committee participation jointly affect the $90.4 \%$ value of the quality of education at the Junior High School in Rokan Hilir.
\end{abstract}

Key words : Headmaster’s Participation, School Committee Participation, Eduaction Quality

ABSTRAK: Penelitian ini bertujuan untuk mengetahui pengaruh peran kepala sekolah dan komite sekolah terhadap mutu pendidikan pada SMP Negeri di kabupaten Rokan Hilir. Penelitian ini dilaksanakan pada SMP Negeri Di Kabupaten Rokan Hilir. Waktu penelitian ini dilaksanakan selama tiga bulan, dari bulan September 2015 hingga November 2015. Hasil penelitian menunjukkan bahwa terdapat hubungan positif antara peran kepala sekolah dengan mutu pendidikan. Secara parsial, peran kepala sekolah mempengaruhi 90,0\% nilai mutu pendidikan pada SMP Negeri di Kabupaten Rokan Hilir, artinya makin baik peran kepala sekolah semakin baik pula mutu pendidikan. Terdapat hubungan positif antara peran komite sekolah dengan mutu pendidikan. Secara parsial, peran komite sekolah mempengaruhi 58,3\% nilai terhadap mutu pendidikan pada SMP Negeri di Kabupaten Rokan Hilir, artinya makin baik peran komite sekolah semakin baik pula mutu pendidikan. Terdapat hubungan positif antara peran kepala sekolah dan peran komite sekolah secara bersama-sama dengan mutu pendidikan. peran kepala sekolah dan peran komite sekolah secara bersama-sama mempengaruhi 90,4\% nilai mutu pendidikan pada SMP Negeri di Kabupaten Rokan Hilir.

Kata Kunci : Mutu Pendidikan, Peran Kepala Sekolah, Peran Komite Sekolah 


\section{PENDAHULUAN}

Kabupaten Rokan Hilir adalah Kabupaten berkembang, sejak mekar dari Kabupaten Bengkalis pada tahun 1999. Pemerintah Kabupaten Rokan Hilir terus berusaha mengejar ketertinggalan dengan Kabupaten lain di provinsi Riau yang lebih maju dibanding dengan Kabupaten Rokan Hilir, dengan melaksanakan percepatan-percepatan pembangunan disegala bidang, tidak terkecuali dibidang pendidikan. Banyak program yang telah dilakukan oleh pemerintah Kabupaten Rokan Hilir untuk memajukan dunia pendidikan. Baik langsung dari pemerintah Kabupaten Rokan Hilir dengan melaksanakan pembangunan sarana dan prasarana yang menunjang dunia pendidikan seperti pembangunan gedung sekolah dan lain sebagainya. Dan melalaui Dinas Pendidikan Kabupaten Rokan Hilir melalui berbagai pelatihan untuk Kepala Sekolah, Guru bahkan Pesert Didik.

Namun sangat disayangkan mutu pendidikan di Rokan Hilir Khusus pada jenjang SMP masih belum sesuai dengan yang diharapkan, ini dapat dibuktikan dengan hasil Evaluasi Diri Sekolah (EDS) yang dilakukan setiap tahun oleh pengawas. Evaluasi diri sekolah adalah telaah dari pemenuhan delapan standar pendidikan disatuan pendidikan/sekolah.

Bila dilihat secara umum pemenuhan delapan standar pendidikan di SMP Negeri Kabupaten Rokan Hilir maka dapat digambarkan sebagai berikut: untuk standar proses masih banyak SMP Negeri di Kabupaten Rokan Hilir dalam perencanaan/pegembangan atau pentusunan silabus untuk semua mata pelajaran tidak memuat Standar Kelulusan (SKL), Standar Isi (SI), dan panduan penyusunan KTSP(Kurikulum Tingkat Satuan Pendidikan). Untuk standar pengelolaan masih banyak SMP Negeri di Kabupaten Rokan Hilir dalam menetapkan, merumuskan visi dan misi tidak sesuai dengan prosedur dan tidak mensosialisasikan dengan warga sekolah.

Untuk standar kompetensi lulusan sekolah belum secara maksimal mengembangkan program-program sekolah dalam rangka meningkatkan hasil belajar siswa, misalnya ekstra kurikuler setiap mata pelajaran. Untuk standar penilaian guru juga belum secara serius dalam mengembangkan indikator pencapaian kompetensi dasar dan teknik penilaian yang sesuai pada saat menyusun silabus mata pelajaran. Untuk standar sarana dan prasarana sekolah belum membuat satu perencanaan untuk pemeliharaan bangunan secara terencana dan periodik, dan sekolah belum membuat perencanaan secara seksama pemanfaatan fasilitas penunjang kegiatan belajar mengajar yang berkualitas, seperti media pembelajaran, perpustakaan, dan laboran.

Untuk standar pembiayaan sekolah dalam menyusun RKS (Rencana Kegiatan Sekolah)/ RKAS (Rencana Kegiatan Dan Anggaran Sekolah) kurang memperhatikan pedoman sesuai Standar Nasional Pendidikan, sehingga RKS/ RKAS tidak sesuai dengan Standar Nasional Pendidikan, dan sekolah dalam memanfaatkan biaya operasional sekolah tidak sesuai dengan RKS/RKAS. Untuk standar isi sekolah belum memenuhi isi muatan kurikulum sebagaimana dipersyaratkan didalam standar isi, seperti kurikulum sekolah belum memuat pendidikan kecakapan hidup. Untuk standar PTK (Pendidik dan Tenaga Kependidikan) di sekolah masih banyak guru dan tenaga administrasi belum memenuhi kualifikasi pendidikan sesuai dengan standar, seperti banyak guru yang belum sarjana (S-1), dan tenaga administrasi yang masih tamatan SMA.

Dari uraian diatas maka dapat disimpulkan bahwa mutu pendidikan pada SMP Negeri Kabupaten Rokan Hilir masih rendah bila ditelaah dari pemenuhan delapan standar nasional pendidikan.

Dari uraian diatas salah satu faktor dalam peningkatan mutu pendidikan adalah kepemimpinan profesional dalam bidang pendidikan. Kepala sekolah sebagai pemimpin pendidikan disekolah bertanggung jawab terhadap mutu pendidikan di sekolah. Kepemimpinan kepala sekolah menjadi salah 
satu faktor penting yang dapat mendorong sumberdaya sekolah untuk mewujudkan visi, misi, tujuan dan sasaran sekolah. Kepala sekolah mampu memobilisasi sumberdaya sekolah, dalam kaitanya dengan perencanaan dan evaluasi program sekolah, pengembangan kurikulum, pembelajaran, pengelolaan ketenagaan, sarana dan sumber belajar, keuangan, pelayanan siswa, hubungan sekolah dengan masyarakat dan penciptaan iklim sekolah, sehingga tercapainya mutu pendidikan sesuai dengan yang diharapkan. Hal ini sesuai dengan hasil dengan penelitian dilakukan Evianis (2015) kepala sekolah berperan pendting dalam peningkatan mutu pendidikan.

Peran serta masyarakat melalui Komite Sekolah memiliki posisi yang amat strategis dalam mengembangkan tanggung jawab masyarakat untuk kemajuan pendidikan. Aspek penting dari peran serta masyarakat malalui Komite Sekolah berkaitan dengan membangun sikap sadar mutu pendidikan pada masyarakat dan mengetahui arti dan pentingnya keberadaan sekolah bagi anakanaknya. Sejak UU No. 22 Tahun 1999 tentang pemerintahan daerah diberlakukan, terjadi perubahan paradigma dalam pengelolaan pemerintahan dari yang bersipat sentralistik kepada disentralistik. Ini tentu memberi harapan baru bagi daerah dan satuan pendidikan untuk dapat memberikan pelayanan pendidikan yang optimal dan bermutu pada masyarakat.

Harapan ini yang juga tidak kalah penting adalah bagaimana mengembalikan pelaksanaan dan partisipasi masyarakat yang hilang akibat pengelolaan pendidikan yang birokratis tersebut, ini penting karena sejak berlakunya Inpres No. 10 Tahun 1973 secara praktis dan tanggung jawab pendidikan, terutama penyelenggaraan pendidikan di sekolah menjadi beban pemerintah pusat, sehingga peran serta dan partisipasi masyarakat hanya sebatas pembiayaan pendidikan. Padahal banyak yang dapat dilakukan masyarakat dalam memberikan kontribusi terhadap sekolah.

Usaha atau kegiatan yang berhubungan dengan pelaksanaan Komite Sekolah dalam peningkatan mutu pendidikan sebuah fenomena untuk mencapai tujuan yang telah ditetapkan, baik berupa pengelolaan, pengambilan keputusan, pengorganisasian, perencanaan, pengawasan, mengkoordinasi usaha, maupun kepemimpinan secara umum. Sehingga peran komite sekolah sangat berpengaruh dalam peningkatan pendidikan di sekolah. Hal ini sejalan dengan hasil penelitian yang dilakukan Armansyah (2009) dengan hasil penelitian bahwa komite sekolah memiliki peran dalam program-program sekolah untuk peningkatan mutu pendidikan.

Berdasar uraian di atas, maka penulis ingin meneliti “ Peran Kepala Sekolah Dan Komite Sekolah Terhadap Mutu Pendidikan Pada SMP Negeri Di Kabupaten Rokan Hilir”.

Tujuan penelitian dapat diuraikan sebagai berikut :

1. Untuk mengetahui peran kepala sekolah dan komite sekolah berpengaruh secara simultan terhadap mutu pendidikan pada SMP Negeri di Kabupaten Rokan Hilir

2. Untuk mengetahui peran kepala sekolah berpengaruh secara parsial terhadap mutu pendidikan pada SMP Negeri di Kabupaten Rokan Hilir?

3. Untuk mengetahui peran komite sekolah berpengaruh secara parsial terhadap mutu pendidikan pada SMP Negeri di Kabupaten Rokan Hilir

Menurut Kamus Besar Bahasa Indonesia pengertian mutu adalah ukuran baik buruk, kadar, taraf, atau derajat suatu benda. Mutu atau kualitas adalah gambaran dan karakteristik menyeluruh dari barang dan jasa yang menunjukkan kemampuannya dalam memuaskan kebutuhan yang diharapkan atau tersirat. Mutu adalah agenda utama dan meningkatkan mutu merupakan tugas yang paling penting. Mutu adalah gambaran dan karakteristik menyeluruh dari barang atau jasa yang menunjukkan kemampuannya dalam memuaskan kebutuhan yang diharapkan oleh pelanggan.

Pengertian mutu dapat dilihat dari dua sisi, yaitu segi normatif dan segi deskriptif, dalam artian 
normatif, mutu ditentukan berdasarkan pertimbangan (kriteria) intrinsik dan ekstrinsik. Berdasarkan kriteria intrinsik, mutu pendidikan merupakan produk pendidikan yakni manusia yang terdidik sesuai dengan standar ideal.

Mutu pendidikan menurut Peraturan Menteri Pendidikan Nasional Nomor 63 Tahun 2009 Pasal 1 Ayat 1 adalah tingkat kecerdasan kehidupan bangsa yang diraih dari penerapan Sistim Pendidikan Nasional. Pengertian ini mengarahkan bahwa mutu pendidikan di Indonesia akan bisa dicapai jika melaksanakan ketentuan ruang lingkup Sistim Pendidikan Nasional yang ada di Undang-Undang Nomor 20 Tahun 2003 yang salah satu penjabaranya adalah Peraturan Pemerintah Nomor 19 Tahun 2005 tentang Standar Nasional Pendidikan.

Peraturan Pemerintah Nomor 19 Tahun 2005 menjelaskan antara lain defenisi Standar Nasional Pendidikan, pasal 2 ayat 1 Lingkup Standar Nasional Pendidikan meliputi: 1) standar isi, 2) standar proses, 3) standar kompetensi lulusan, 4) standar pendidik dan tenaga kependidikan, 5) standar sarana dan prasarana, 6) standar pengelolaan, 7) standar pembiayaan, 8) standar penilaian pendidikan, dan ayat 2, berbunyi untuk penjaminan dan pengendalian mutu pendidikan sesuai dengan Standar Nasional Pendidikan dilakukan evaluasi, akreditasi, dan sertifikasi.

Dalam bahasa inggris peran (role) berarti tugas. Sedangkan dalam kamus besar bahasa Indonesia peran berarti seperangkat tingkah yang diharapkan dimiliki oleh orang yang berkedudukan dimasyarakat. Dari pengertian diatas yang dimaksud adalah peran atau tugas kepala sekolah. Secara sederhana kepala sekolah dapat didefinisikan sebagai seorang tenaga fungsional guru yang diberi tugas untuk memimpin suatu sekolah dimana diselenggarakan proses belajar menggajar atau tempat dimana terjadi interaksi antara guru yang memberi pelajaran dan siswa yang menerima pelajaran. Kepala sekolah sebagai individu yang bertanggung jawab di sekolah mempunyai kewajiban untuk berusaha agar semua potensi yang ada pada lembaganya dapat dimanfaatkan sebaik-baiknya demi tercapainya tujuan yang diharapkan.

Menurut Peraturan Pemerintah Nomor 74 Tahun 2008 Tentang Guru, Pasal 15 ayat 3 dinyatakan bahwa jabatan kepala sekolah adalah tugas tambahan yang diberikan kepada guru yang telah bersertifikat profesi di satuan pendidikan dengan beban kerja satuan pendidikan. Implementasi tugas tersebut tertuang dalam Peraturan Menteri Pendidikan Nasional Nomor 28 Tahun 2010 tentang penugasan guru sebagai kepala sekolah, pasal 12 yang secara garis besar dapat dirangkum dalam tiga aspek yaitu: usaha pengembangan sekolah/madrasah, peningkatan kualitas sekolah/madrasah berdasarkan 8 (delapan) standar nasional pendidikan, dan usaha pengembangan profesionalisme sebagai kepala sekolah/madrasah.

Peraturan Menteri Pendidikan Nasional Nomor 28 Tahun 2010 Pasal 12 tentang Penugasan Guru sebagai Kepala Sekolah/ Madrasah menyatakan bahwa guru yang diberi tugas tambahan sebagai kepala sekolah/ madrasah dinilai kinerjanya secara berkala setiap tahun dan secara kumulatif selama 4 tahun yang akan dijadikan dasar bagi promosi atau demosi yang bersangkutan. Penilaian kinerja tersebut dilakukan berdasarkan implementasi tugas pokok dan fungsi (tupoksi) sebagai kepala sekolah/madrasah.

Berdasarkan Permendiknas Nomor 13 Tahun 2007, penilaian kinerja kepala sekolah/ madrasah dimaksudkan untuk menilai sejauh mana seorang kepala sekolah/madrasah mengejawantahkan kompetensi-kompetensi yang dipersyaratkan dalam melaksanakan tugas dan fungsinya sehari-hari. Kompetensi-kompetensi itu dikelompokkan kedalam 6 (enam) aspek penilaian yakni kompetensi, a) kepribadian dan sosial, b) kepemimpinan pembelajaran, c) pengembangan sekolah, d) manajemen sumber daya, e) kewirausahaan, dan f) supervisi pembelajaran.

Disetiap organisasi posisi dan peran pemimpin selalu sangat sentral, maju dan 
mundurnya organisasi sangat tergantung pada sejauh mana pimpinan mampu berimajinasi untuk memajukan organisasinya. Demikian pula dalam konteks sekolah sebagai organisasi, maka posisi kepala sekolah juga sangat penting dalam memajukan lembaga yang dipimpinya. Erat hubungannya antara mutu kepala sekolah seperti disiplin sekolah, iklim budaya sekolah, dan menurunnya perilaku peserta didik. Dalam pada itu kepala sekolah bertanggungjawab atas manajemen pendidikan secara mikro, yang secara langsung berkaitan dengan proses pembelajaran disekolah. Maka dapat dipahami bahwa kepala sekolah sebagai seorang yang bertanggung jawab atas mutu pendidikan disekolah. Artinya bahwa peran kepala sekolah sebagai pemimpin disekolah sangat berpengaruh terhadap baik buruknya mutu pendidikan disekolah yang ia pimpin.

Indikator peran kepala sekolah dapat dilihat dari pemenuhan kompetensi kepala sekolah sesuai dengan yang dipersyaratkan, yang meliputi: 1). kompetensi kepribadian dan sosial,

2). kompetensi kepemimpinan pembelajaran,

3). kompetensi pengembangan sekolah,

4). kompetensi manajemen sumber daya,

5). kompetensi kewirausahaan, dan

6). kompetensi supervisi pembelajaran.

Berdasarkan uraian daiatas, dapat disimpulkan bahwa Peran Kepala sekolah adalah sebagai pemimpin sentral di sekolah yang bertanggung jawab terhadap pengembangan sekolah, peningkatan kualitas sekolah berdasarkan 8 (delapan) standar nasional pendidikan, dan pengembangan profesionalisme sebagai kepala sekolah dengan memenuhi kompetensi; kepribadian dan sosial, kepemimpinan pembelajaran, pengembangan sekolah, manajemen sumber daya, kewirausahaan, dan supervisi pembelajaran.

Dalam Pasal 188 (2) PP Nomor 17 Tahun 2010 tentang Pengelolaan dan Penyelenggaraan Pendidikan, peran serta masyarakat telah dirumuskan sebagai berikut. Masyarakat menjadi sumber, pelaksana, dan pengguna hasil pendidikan. Oleh karena itu, masyarakat mempunyai peran dalam bentuk (a) penyediaan sumber daya pendidikan, (b) penyelenggaraan satuan pendidikan, (c) penggunaan hasil pendidikan, (d) pengawasan penyelenggaraan pendidikan, (e) pengawasan pengelolaan pendidikan, (f) pemberian pertimbangan dalam pengambilan keputusan yang berdampak pada pemangku kepentingan pendidikan pada umumnya; dan/atau (g) pemberian bantuan atau fasilitas kepada satuan pendidikan dan/atau penyelenggara satuan pendidikan dalam menjalankan fungsinya. Cukup banyak dan beragam kemungkinan peran yang dapat ditunaikan oleh masyarakat dalam urusan pendidikan.

Dalam PP Nomor 17 Tahun 2010 dijelaskan dengan lebih gamblang bahwa Dewan Pendidikan dan Komite Sekolah mempunyai tugas memberikan pertimbangan kepada birokrasi pendidikan. Dalam Pasal 192 (2) dengan tegas dijelaskan bahwa "Dewan Pendidikan dan Komite Sekolah berfungsi dalam peningkatan mutu pelayanan pendidikan dengan memberikan pertimbangan, arahan dan dukungan tenaga, sarana dan prasarana, serta pengawasan pendidikan pada tingkat nasional, provinsi, dan kabupaten/kota”.

Lebih lanjut dalam Kepmendiknas nomor 044/u/2002 dijelaskan bahwa Komite Sekolah berfungsi : 1) Mendorong tumbuhnya perhatian dan komitmen masyarakat terhadap penyelenggaraan pendidikan yang bermutu, 2) Melakukan kerjasama dengan masyarakat (perorangan / organisasi / duniausaha / duniaindustri) dan pemerintah berkenaan dengan penyelenggaraan pendidikan yang bermutu, 3) Menampung dan menganalisis aspirasi, ide, tuntutan, dan berbagai kebutuhan pendidikan yang diajukan oleh masyarakat, 4) Memberikan masukan, pertimbangan, dan rekomendasi kepada satuan pendidikan mengenai: kebijakan dan program pendidikan, Rencana Anggaran Pendidikan dan Belanja Sekolah (RAPBS), kriteria kinerja satuan pendidikan, kriteria tenaga kependidikan, kriteria fasilitas pendidikan; dan hal-hal lain yang terkait dengan pendidikan, 5) 
Mendorong orangtua dan masyarakat berpartisipasi dalam pendidikan gunamendukung peningkatan mutu dan pemerataan pendidikan, 6) Menggalang dana masyarakat dalam rangka pembiayaan penyelenggaraan pendidikan disatuan pendidikan, 7) Melakukan evaluasi dan pengawasan terhadap kebijakan, program, penyelenggaraan, dan keluaran pendidikan di satuan pendidikan.

Dalam Pasal 192 (2) PP Nomor 17 Tahun 2010 merupakan penjabaran dari Pasal 56 (3) UU Nomor 20 Tahun 2003 tentang Sistem Pendidikan Nasional, yang di dalam Panduan Umum Dewan Pendidikan dan Komite Sekolah disebutkan sebagai peran dan fungsi Dewan Pendidikan dan Komite Sekolah, dalam Pasal 192 (3) disebutkan bahwa fungsi Dewan Pendidikan dan Komite Sekolah adalah meningkatkan mutu layanan pendidikan.

Dalam Kepmendiknas nomor 044/u/2002, komite sekolah berperan: 1) Pemberi pertimbangan (advisory agency) dalam penentuan dan pelaksanaan kebijakan pendidikan di satuan pendidikan, 2) Pendukung (supporting agency), baik yang berwujud financial, pemikiran maupun tenaga dalam penyelenggaraan pendidikan di satuan pendidikan, 3) Pengontrol (controlling agency) dalam rangka transparansi dan akuntabilitas penyelenggaraan dan keluaran pendidikan di satuan pendidikan, 4) Mediator antara pemerintah (eksekutif) dengan masyarakat di satuan pendidikan.

Berdasarkan uraian diatas maka dapat disimpulkan bahwa, peran komite sekolah adalah badan mandiri yang mewadahi peran serta masyarakat dalam rangka meningkatkan mutu, pemerataan, dan efisiensi pengelolaan pendidikan di satuan pendidikan dengan peran sebagai pemberi pertimbangan (advisory agency), pendukung (supporting agency), pengontrol (controlling agency), dan mediator antara pemerintah (eksekutif).

Berdasarkan kerangka berpikir dapat diajukan hipotesis penelitian sebagai berikut:

1. Terdapat pengaruh positif peran kepala sekolah terhadap mutu pendidikan
2. Terdapat pengaruh positif peran komite sekolah terhadap mutu pendidikan

3. Terdapat pengaruh positif peran kepala sekolah dan komite sekolah secara bersama-sama terhadap mutu pendidikan.

\section{METODE PENELITIAN}

Sesuai dengan hipotesis yang diajukan, maka tujuan penelitian ini ialah untuk mendapatkan data empiris tentang adanya pengaruh antara variabelvariabel: 1) Peran kepala sekolah terhadap mutu pendidikan pada SMP Negeri di Kabupaten Rokan Hilir, 2) Peran komite sekolah terhadap mutu pendidikan pendidikan pada SMP Negeri di Kabupaten Rokan Hilir, dan 3) Peran kepala sekolah dan komite sekolah secara bersamasama terhadap mutu pendidikan pendidikan pada SMP Negeri di Kabupaten Rokan Hilir.

Penelitian ini dilaksanakan pada SMP Negeri Di Kabupaten Rokan Hilir. Waktu penelitian ini dilaksanakan selama tiga bulan, dari bulan September 2015 hingga November 2015.

Populasi penelitian ini adalah kepala sekolah, komite, dan SMP Negeri di Kabupaten Rokan Hilir. Jumlah populasi adalah 40 kepala sekolah, komite, dan SMP Negeri yang tersebar di Kabupaten Rokan Hilir, seluruh populasi dijadikan sampel.

\section{HASIL DAN PEMBAHASAN \\ Pengaruh Peran Kepala Sekolah dengan Mutu Pendidikan}

Pada penelitian ini uji hipotesis $0\left(\mathrm{H}_{0}\right)$ dinyatakan bahwa tidak terdapat pengaruh yang positif antara peranan kepala sekolah dengan mutu pendidikan, dengan hipotesis alternatif $\left(\mathrm{H}_{\mathrm{a}}\right)$ yang menyatakan terdapat pengaruh yang positif antara peranan kepala sekolah dengan mutu pendidikan. Pengujian hipotesis tersebut dilakukan dengan menggunakan teknis analisis regresi dan korelasi sederhana.

Dari hasil perhitungan regresi sederhana peranan kepala sekolah dengan mutu pendidikan diperoleh korelasi antara peranan kepala sekolah dengan mutu pendidikan adalah 0,949 dengan ketentuan jika koefisien korelasi berarti bilat ${ }_{\text {hitung }}$ 
$>\mathrm{t}_{\text {tabel }}$ pada $\mathrm{n}=40$ signifikansi 0,05. Maka Ha diterima dan Ho ditolak artinya terdapat hubungan yang signifikan antara peranan kepala sekolah dengan mutu pendidikan. Untuk lebih jelasnya dilihat dari r tabel produk momen pada tabel 4.7.

\section{Tabel 4.1 Hasil Korelasi Product Moment Pengaruh Peran Kepala Sekolah $\left(\mathrm{X}_{1}\right)$ dengan Mutu Pendidikan(Y)}

\begin{tabular}{lccccc}
\hline \multicolumn{1}{c}{ Variable } & $\begin{array}{c}\text { koefisien } \\
\text { korelasi }\end{array}$ & $\begin{array}{c}\text { koefisisen } \\
\text { determinasi }\end{array}$ & t hitung & $\begin{array}{c}\mathrm{t} \text { table } \\
\alpha=0,05\end{array}$ & $\begin{array}{c}\mathrm{t} \text { table } \\
\alpha=0,01\end{array}$ \\
\hline $\begin{array}{l}\text { peranan } \\
\text { kepala } \\
\text { sekolah } \\
\text { dengan mutu } \\
\text { pendidikan }\end{array}$ & 0,949 & 0,900 & 18,590 & 1,68 & 2,42 \\
\end{tabular}

Pada tabel diketahui koefisien korelasi antara peran kepala sekolah dengan mutu pendidikan pada $n=40$ adalah 0,949 yang berarti pearson korelasi atau $r$ hitung $(0,949)$ dengan koefisien determinasi (r2) $=0,900$ atau 90,0\% artinya besarnya pengaruh peran kepala sekolah terhadap mutu pendidikan adalah $90,0 \%$, sedangkan sisanya dipengaruhi oleh faktor lain. Uji keberartian koefisien korelasi $r_{\mathrm{y} 1}$ dapat dilihat dari perhitungan t hitung $=18,590$ $>$ t tabel 1,68. Dengan kata lain koefisien korelasi antara peran kepala sekolah $\left(\mathrm{X}_{1}\right)$ dengan mutu pendidikan (Y) “berarti”.

\section{Pengaruh Peran Komite Sekolah Dengan} Mutu Pendidikan

Pada penelitian ini uji hipotesis $0\left(\mathrm{H}_{0}\right)$ dinyatakan bahwa tidak terdapat pengaruh yang positif antara peran komite sekolah dengan mutu pendidikan. Melawan hipotesis alternatif $\left(\mathrm{H}_{\mathrm{a}}\right)$ yang menyatakan terdapat pengaruh positif antara peran komite sekolah dengan mutu pendidikan. Pengujian hipotesis tersebut dilakukan dengan menggunakan teknis analisis regresi dan korelasi sederhana dengan manual.

Dari hasil perhitungan regresi sederhana peran komite sekolah dengan mutu pendidikan diperoleh korelasi antara peran komite sekolah dengan mutu pendidikan adalah 0,967 dengan ketentuan jika koefisien korelasi berarti bila $\mathrm{t}_{\text {hitung }}$ $>\mathrm{t}_{\text {tabel }}$ pada $\mathrm{n}=40$ signifikansi 0,05. Maka Ha diterima dan Ho ditolak artinya terdapat Hubungan yang signifikan antara peran komite sekolah dengan mutu pendidikan. Untuk lebih jelasnya dilihat dari $r$ table product moment pada tabel 4.8

Tabel 4.2 Hasil Korelasi Product Moment Pengaruh Peran Komite Sekolah $\left(\mathrm{X}_{2}\right)$ Dengan Mutu Pendidikan (Y)

\begin{tabular}{llllcc}
\hline Variable & $\begin{array}{l}\text { koefisien } \\
\text { korelasi }\end{array}$ & $\begin{array}{l}\text { koefisisen } \\
\text { determinasi }\end{array}$ & t hitung & $\begin{array}{l}\mathrm{t} \text { table } \\
\alpha=0,05\end{array}$ & $\begin{array}{l}\mathrm{t} \text { table } \\
\alpha=0,01\end{array}$ \\
\hline $\begin{array}{l}\text { peran komite } \\
\text { sekolah dengan } \\
\text { mutu pendidikan }\end{array}$ & 0,967 & 0,936 & 138,483 & 1,68 & 2,42 \\
\hline
\end{tabular}


Pada tabel diketahui koefisien korelasi antara peran komite sekolah dengan mutu pendidikan pada $n=40$ adalah 0,967 yang berarti pearson korelasi atau $r$ hitung $(0,967)$ dengan koefisien determinasi $\left(\mathrm{r}^{2}\right)=0,936$ atau 93,6\% artinya besarnya pengaruh peran komite sekolah terhadap mutu pendidikan adalah 93,6\% sedangkan sisanya dipengaruhi oleh faktor lain. Uji keberartian koefisien korelasi $r_{\mathrm{y} 2}$ dapat dilihat dari perhitungan thitung $=138,483>\mathrm{t}$ tabel 1,68 dengan kata lain koefisien peran komite sekolah $\left(\mathrm{X}_{2}\right)$ dengan mutu pendidikan $(\mathrm{Y})$ "berarti”.

\section{Pengaruh Peran Kepala Sekolah Dan Peran} Komite Sekolah Dengan Mutu Pendidikan

Pengujian hipotesis ini dilakukan dengan menggunakan teknis analisis regresi dan korelasi ganda dengan bantuan program SPSS. Perhitungan korelasi ganda antara peran kepala sekolah $\left(\mathrm{X}_{1}\right)$ dan peran komite sekolah $\left(\mathrm{X}_{2}\right)$ dengan mutu pendidikan (Y) memberikan korelasi koefisien korelasi ganda (r) sebesar 0,982

\section{Tabel 4.3 Hasil Korelasi Kualitas kehidupan kerja $\left(X_{1}\right)$ dan Insentif $\left(X_{2}\right)$ dengan Motivasi berprestasi guru (Y)}

\begin{tabular}{lll}
\hline Variabel & Koefisien Korelasi & Koefisien Determinasi \\
\hline PERAN KEPALA & & \\
SEKOLAH,PERAN & & \\
KOMITE SEKOLAH, & & 0,964 \\
MUTU PENDIDIKAN & 0,982 & \\
\hline
\end{tabular}

Pada tabel diketahui korelasi antara peran komite sekolah $\left(\mathrm{X}_{1}\right)$ dan peran komite sekolah $\left(\mathrm{X}_{2}\right)$ terhadap mutu pendidikan $(\mathrm{Y})$ secara bersama-sama adalah 0,982. Koefisien determinasi $\left(\mathrm{r}^{2}\right)=0,964$ atau $96,4 \%$ artinya besarnya pengaruh peran kepala sekolah $\left(\mathrm{X}_{1}\right)$ dan peran komite sekolah $\left(\mathrm{X}_{2}\right)$ secara bersamasama terhadap mutu pendidikan (Y) adalah 96,4\% sedangkan sisanya dipengaruhi oleh faktor lain.

\section{Tabel 4. 4 Analisis Variansi (Anova) Peran Kepala Sekolah (X1) dan Peran Komite Sekolah (X2) dengan Mutu Pendidikan (Y)}

\begin{tabular}{|c|c|c|c|c|c|c|}
\hline $\mathrm{SV}$ & $\mathrm{df}$ & $\mathrm{JK}$ & RJK & F Hitung & $\begin{array}{l}\mathrm{F} \text { tabel } \\
(0.05)\end{array}$ & $\begin{array}{l}\text { F tabel } \\
(0.01)\end{array}$ \\
\hline Total & 39 & 0.15 & 0.003804 & & & \\
\hline $\begin{array}{l}\text { Regresi } \\
\text { (b/a) }\end{array}$ & 2 & 0.14 & 0.071525 & 497.9597 & 3.01 & 6.41 \\
\hline Sisa & 37 & 0.01 & 0.000144 & & & \\
\hline
\end{tabular}

Uji keberartian regresi ganda $\mathrm{F}_{\text {hitung }}=$ 497,9597 $>\mathrm{F}_{\text {tabel }=}(6,41 ; \mathrm{a}=0.01)$ dengan demikian bentuk regresi $\mathrm{Y}$ atas $\mathrm{X}_{1}$ dan $\mathrm{X}_{2}$ adalah sangat signifikan.
Tabel anova menunjukkan $F$ hitung sebesar $=$ 497,9597 dengan $\mathrm{df} 1$ = derajat kebebasan pembilang 2 dan df2 = derajat kebebasan penyebut 37. Dengan membandingkan F tabel 
dengan $\mathrm{df} 1=2$ dan $\mathrm{df}=37$ untuk taraf signifikasi 5\% yaitu 3,01 dan 1\% yaitu 6,41. Maka F hitung 497,9597 > F tabel $(3,01$ dan 6,41) berarti Ha diterima dan Ho ditolak, artinya terdapat pengaruh yang signifikan antara peran kepala sekolah $\left(\mathrm{X}_{2}\right)$ dan peran komite sekolah $\left(\mathrm{X}_{2}\right)$ terhadap mutu pendidikan(Y).

Persamaan regresi ganda $\mathrm{Y}=\mathrm{a}+\mathrm{b} 1 \mathrm{X}_{1}$ $+\mathrm{b} 2 \mathrm{X}_{2}$, berdasarkan hasil diperoleh persamaan regresi adalah:

$$
\mathrm{Y}=1,644+0,007 \mathrm{X} 1+0,002 \mathrm{X} 2 \text {. }
$$

Yakni harga persamaan regresi digunakan untuk melakukan ramalan (forecasting/estimasi) bagaimana pengaruh variabel indepedent terhadap besarnya perubahan variabel dependen. Untuk menguji signifikansi koefisien korelasi ganda, dapat dilihat pada $\mathrm{F}_{\text {hitung }}=$ 497,9597 sedangkan $\mathrm{F}_{\text {tabeL }}$ 3,01 dengan pembilang 2 dan $\mathrm{dk}=37$ pada taraf 0,01 sebesar 6,41 . Oleh karena $F_{\text {hitung }}>F_{\text {tabel }}$ maka dapat diartikan bahwa regresi eran kepala sekolah $\left(\mathrm{X}_{1}\right)$ dan peran komite sekolah $\left(\mathrm{X}_{2}\right)$ terhadap mutu pendidikan $(\mathrm{Y})$ dengan persamaan regresi $\mathrm{Y}=$
$1,644+0,007 \mathrm{X} 1+0,002 \mathrm{X} 2$. Terdapat hubungan antara peran kepala sekolah dan peran komite sekolah dengan mutu pendidikan pada SMP Negeri di Kabupaten Rokan Hilir.

Koefisien determinasi $\left(\mathrm{R}^{2}\right)$ adalah sebesar 0,982 yang berada pada kategori tinggi. Ini menunjukkan bahwa variansi yang terjadi pada mutu pendidikan pada SMP Negeri di Kabupaten Rokan Hilir dapat dijelaskan oleh peran komite sekolah dan peran komite sekolah, melalui persamaan regresi $Y=1,644+0,007 \mathrm{X} 1$ $+0,002 X 2$.

Berdasarkan persamaan regresi tersebut dapat diartikan bahwa kenaikan satu nilai peran kepala sekolah akan diikuti oleh peningkatan mutu pendidikan sebesar 0,007 apabila variabel Insentif dalam konstan. Begitu juga sebaliknya, kenaikan satu nilai peran komite sekolah akan diikuti oleh peningkatan mutu pendidikan sebesar 0,002 apabila variabel kualitas kehidupan kerja dalam konstan. Pola hubungan ketiga variabel penelitian dapat digambarkan pada gambar 4.4

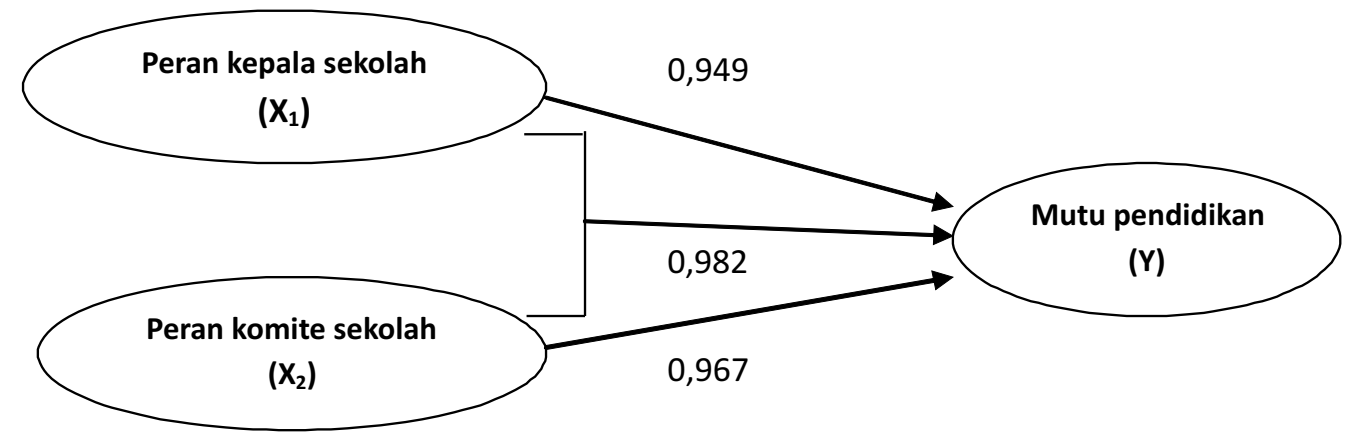

Gambar 4. 1 Pola Pengaruh antara Variabel Penelitian

\section{SIMPULAN DAN SARAN}

Berdasarkan pengujian hipotesis dan pembahasan hasil penelitian, pada bab ini akan dibicarakan simpulan, implikasi, dan saran yang bersifat sintetik dan sistematik, untuk lebih jelasnya akan dikemukakan satu persatu.

Dari hasil penelitian diperoleh simpulan sebagai berikut :

1. Terdapat pengaruh positif antara peran kepala sekolah dengan mutu pendidikan.
Secara parsial, peran kepala sekolah mempengaruhi $90,0 \%$ nilai mutu pendidikan pada SMP Negeri di Kabupaten Rokan Hilir, artinya makin baik peran kepala sekolah semakin baik pula mutu pendidikan.

2. Terdapat pengaruh positif antara peran komite sekolah dengan mutu pendidikan. Secara parsial, peran komite sekolah mempengaruhi 58,3\% nilai terhadap mutu pendidikan pada SMP Negeri di Kabupaten 
Rokan Hilir, artinya makin baik peran komite sekolah semakin baik pula mutu pendidikan.

3. Terdapat pengaruh positif antara peran kepala sekolah dan peran komite sekolah secara bersama-sama dengan mutu pendidikan. peran kepala sekolah dan peran komite sekolah secara bersama-sama mempengaruhi 90,4\% nilai mutu pendidikan pada SMP Negeri di Kabupaten Rokan Hilir.

\section{Implikasi}

1. Hasil analisis tentang pengaruh antara peran kepala sekolah dengan mutu pendidikan pada SMP Negeri di Kabupaten Rokan Hilir, menunjukkan hubungan yang positif. Artinya, peran kepala sekolah dapat ditingkatkan jika pihak pimpinan dan guru di sekolah mendukung untuk peran kepala sekolah. Temuan tersebut memberikan arti upaya peningkatan peran kepala sekolah merupakan upaya peningkatan mutu pendidikan.

2. Hasil analisis tentang pengaruh antara peran komite sekolah dengan mutu pendidikan pada SMP Negeri di Kabupaten Rokan Hilir, menunjukkan hubungan yang positif. Artinya mutu pendidikan dapat ditingkatkan jika ada peran komite sekolah dengan baik. Temuan tersebut memberikan arti upaya peningkatan peran komite sekolah merupakan upaya peningkatan terhadap Motivasi mutu pendidikan.

\section{Saran}

Berdasrkan hasil penelitian, simpulan dan implikasi penelitian seperti yang dipaparkan sebelumnya, maka pada bagian ini perlu diberikan saran kepada pihak yang terkait dengan penelitian ini.

1. Pengaruh antara peran kepala sekolah dan peran komite sekolah terhadap mutu pendidikan adalah positif, maka perlu pertimbangan upaya-upaya untuk melakukan peningkatan terhadap peran kepala sekolah dan peran komite sekolah yang lebih baik, meskipun secara bertahap.
Pimpinan sekolah hendaknya lebih mempertimbangkan masukan atau ide tenaga kependidikan dalam pengambilan keputusan sesuai dengan kondisi mental tenaga kependidikan.

2. Untuk memudahkan dan membantu dalam pembentukan peran kepala sekolah dan peran komite sekolah yang baik, perlu adanya diskusi yang baik antara pimpinan sekolah dengan guru. Hal ini penting untuk melibatkan guru dalam setiap kebijakan yang diambil oleh kepala sekolah.

3. Peningkatan peran kepala sekolah dan peran komite sekolah dalam rangka peningkatan hubungan antara pimpinan dengan bawahannya, pembentukan kondisi yang baik, hubungan sosial diantara guru, sugesti dari teman kerja, dan emosi serta situasi kerja yang baik serta motivasi untuk bekerja. Hal ini bisa dilakukan dengan mengetahui keadaan keluarga guru, menjenguk guru yang sakit atau mendapat musibak dan usaha pendekatan lainnya.

4. Mutu pendidikan sekolah juga dapat ditingkatkan melalui peningkatan aktivitas pimpinan sekolah dengan sesama guru. Peningkatan aktivitas diskusi dengan komite sekolah Peningkatan aktivitas ini bertujuan untuk mengetahui masalah-masalah guru dalam mengajar ataupun masalah perekonomian mereka. Hal ini bisa dilakukan dalam rapat atau dengan pendekatan pribadi pimpinan sekolah.

5. Untuk kesempurnaan dan kelanjutan penelitian ini, penelitian selanjutnya dapat dilakukan dengan lebih memperdalam materi dari masing-masing variabel seperti hubungan sosial diantara guru, sugesti teman kerja, dan emosi serta situasi kerja untuk peningkatan mental, dan komunikasi antar pribadi, konflik, dan berafiliasi, promosi jabatan, peningkatan kesejahteraan guru, pembagian tugas pola kepemimpinan 


\section{DAFTAR PUSTAKA}

Alex Aldha Yudi. 2012. Pengembangan Mutu Pendidikan Ditinjau Dari Segi Sarana Dan Prasarana (Sarana Dan Prasarana Pplp), Padang, Remaja Rosdakarya

Amin Budiati. 2009. Peran Kepala Sekolah dalam peningkatan Mutu Pendidikan Sekolah Dasar.Universitas Islam Negeri Sunan Kalijaga.

Armansyah. 2000. Peranan Dan Pemberdayaan Komite Sekolah Dalam Penyelenggaraan Pendidikan SMA Negeari di Kota Binjai, Universitas Sumatera Utara, Medan

Armansyah. 2009. Perananan Dan Pemberdayaan Komite sekolah Dalam Penyelenggaraan Pendidikan Di SMA Negeri Di Kota Binjai, USU.

B. Suryosubroto. 2008. Proses Belajar Mengajar di Sekolah . Jakarta. Rineka Cipta

Depdikbud, Kamus Besar Bahasa Indonesia. Jakarta : Balai Pustaka

Donni Juni Priansa, dkk. 2014. Manajemen Supervisi \& Kepemimpinan Kepala Sekolah. Bandung. Alfabeta.

E. Mulyasa. 2011. Pendidikan Bermutu Dan Berdaya Saing, Bandung, Remaja Rosdarkya.

E. Mulyasa, 2004, Menjadi Kepala Sekolah Profesional, (Dalam Konteks Menyukseskan MBS \& MBK) Bandung, Remaja Rosdakarya

Edward Sallis. 2010. Total Quality Management In Education, terjemah. IRCSoD : Jogjakarta

Erni Purwandari, Pengaruh Kepemimpinan Kepala Sekolah Dan Peran Komite Sekolah Terhadap Keberhasilan Manajemen Berbasis Sekolah Dasar negeri di Kabupaten Batng. Universtas Terbuka. Jakarta.

Ery Djatmika. 2008. Pengaruh Kepemimpinan Kepala Sekolah Terhadap Pembelajaran Organisasional Dan Dampaknya Pada Prilaku Positif Calon Pendidik Ekonomi
Evianis. 2015. Manajemen Kepela Sekolah Dalam Upaya Meningkatkan Mutu Pendidikan SDN Di Kecapamatan Langgam Kabupaten Pelalawan, UR.

Imam Musbikin. 2013. Menjadi Kepala Sekolah Yang Hebat, Zanafa Publising, Pekan Baru.

Imam Sibaweh. 2013. Pengaruh Prilaku Kepemimpinan Kepala Sekolah Dan Iklim Sekolah Terhadap Mutu Sekolah Pada SMPN Di Kabupaten Cirebon, Universitas Pendidikan Indonesi

Imam Suprayogi. 2004. Pendidikan Berparadigma Al-Quran, Aditya Media \& UIN Malang Press, Malang

Jerome S. Arcaro. 2007. Pendidikan Berbasis Mutu, Prinsip-prinsip dan Tata Langkah Penerapan, Perpustakaan Pelajar, Yogyakarta

Nana Syaodih Sukmadinata, dkk. 2006. Pengendalian Mutu Pendidikan Sekolah Menengah.Bandung.PT Refika Aditama.

Nurkholis. 2006. Manajemen Berbasis Sekolah Teori, Model, Dan Aplikasi, Bandung, Grasindo.

Peter Salim. 1996. The Contemporary English Indonesia Dictionar, Jakarta Modern English Press,

Reny Novianti. 2013. Kontribusi Kepemimpinan Transformasional Kepala Sekolah dan Kinerja Mengajar Guru Terhadap Mutu Sekolah Dasar di Kecamatan Jombang Banten, Universitas Pendidikan Indonesia

Siska Yuni Larasati. 2009. Peran Komite Sekolah Dalam Meningkatkan Mutu Pendidikan Di SMA Ronggolaweh Kota Semarang. Universitas Negeri Semarang. Syaiful Sagala. 2007. Manajemen Strategik Dalam Peningkatan Mutu Pendidikan, Alfabeta, Bandung.

Tim Dosen Administrasi Pendidikan Universitas Pendidikan Indonesia. 2008. Manajemen Pendidikan, ALFABETA, Bandung. Wahyu Sumidjo. 2003. Kepemimpinan Kepala Sekolah, Jakarta, Raja Grafindi Persada 